\title{
Essential Oil Content and Chemical Composition of Lippia gracilis Schauer Cultived in the Sub-meddle São Francisco Valley
}

\author{
Ana Valéria Vieira de Souza, Uiliane Soares dos Santos, Ricardo Monteiro \\ Corrêa, Danilo Diego de Souza \& Flávio José Vieira de Oliveira
}

To cite this article: Ana Valéria Vieira de Souza, Uiliane Soares dos Santos, Ricardo Monteiro Corrêa, Danilo Diego de Souza \& Flávio José Vieira de Oliveira (2017) Essential Oil Content and Chemical Composition of Lippia gracilis Schauer Cultived in the Sub-meddle São Francisco Valley, Journal of Essential Oil Bearing Plants, 20:4, 983-994, DOI: 10.1080/0972060X.2017.1377117

To link to this article: http://dx.doi.org/10.1080/0972060X.2017.1377117

\section{Published online: 13 Oct 2017.}

Submit your article to this journal ¿

View related articles $\longleftarrow$

View Crossmark data〔 


\title{
Essential Oil Content and Chemical Composition of Lippia gracilis Schauer Cultived in the Sub-meddle São Francisco Valley
}

\author{
Ana Valéria Vieira de Souza ${ }^{1 *}$, Uiliane Soares dos Santos ${ }^{1}$, Ricardo Monteiro \\ Corrêa $^{2}$, Danilo Diego de Souza ${ }^{1}$, Flávio José Vieira de Oliveira ${ }^{3}$ \\ ${ }^{1}$ Embrapa Semiárido - Centro de Pesquisa Agropecuária do Trópico \\ Semiárido (CPATSA), 56302-970, Petrolina, PE, Brazil \\ ${ }^{2}$ IFMG, Campus Bambuí, Bambuí, MG, Brazil \\ ${ }^{3}$ Uneb, Campus III, Juazeiro, BA, Brazil
}

Received 12 January 2017; accepted in revised form 16 June 2017

\begin{abstract}
Lippia gracilis is a native species of the Caatinga, whose leaves have significant potential for economic use by chemical and pharmaceutical industries due to the presence of thymol and carvacrol. Considering the lack of agronomic data for the species, especially for semi-arid conditions where it is possible to find natural populations, the aim of this work was to assess the effects of drought and different doses of organic fertilization in biomass production and content, yield and chemical composition of the essential oil. The experiment was conducted with 16 treatments that consisted of presence and absence of organic fertilizer, mineral fertilizer and irrigation. The analyzed variables after 120 days of culture were: total length until the last leaf, fresh weight of aerial parts with stem, leaf dry weight and fresh weight, content and chemical composition of essential oil, and moisture. In the conditions where this study was conducted, it was observed that the organic and mineral fertilization and irrigation positively influenced the production of biomass and essential oil content. However, cultivation methods did not significantly affect the chemical composition of essential oils, which shows the hardiness of the species to changes in availability of water and nutrients.
\end{abstract}

Keywords: Verbenaceae, Caatinga, thymol, carvacrol, irrigation.

\section{Introduction}

Lippia gracilis Schauer (Verbenaceae) is a native species of Caatinga, popularly known as the hinterland rosemary, bush rosemary, rosemary of the plateau or board rosemary, with sized shrub, up to $2 \mathrm{~m}$ tall. Its leaves, are aromatic and spicy and its flowers are small, whitish and assembled in short axis stalks. Fruits are achene of extremely small size, whose seeds rarely germinate and its propagation can be accomplished through cutting thinner and less lignified branches ${ }^{1,2,3}$.

The leaves and flowers of this species have been widely used in popular medicine for the treatment

*Corresponding author (Ana Valéria Vieira de Souza) E-mail: < ana.souza@embrapa.br > of skin diseases, external injuries, burns, wounds and ulcers, because of the wound healing effect of its essential oil ${ }^{1}$. Albuquerque et al. ${ }^{4}$ reported the use of the bush rosemary for several rural communities in the Brazilian semiarid. Mendes et al. ${ }^{3}$ also reported the analgesic and anti-inflammatory effect of the essential oil directly extracted from the leaves. The essential oil shows high potential for economic exploitation by chemical and pharmaceutical industries, with effective antimicrobial activity, such as carvacrol, thymol and ñcymene ${ }^{4,5,6}$.

Studies to evaluate the effect of different types

(c) 2017, Har Krishan Bhalla \& Sons 
and levels of fertilizer in production, yield and chemical composition of essential oil have already been made for the species L. alba and L. sidoides $7,8,9$. However, there are no references in this context of researches carried with L. gracilis. Access to this plant is mainly by extractive means and agronomic studies conducted so far boil down to propagation methods ${ }^{10}$ and the influence of seasonality in essential oil production ${ }^{11}$.

Considering the high potential of that species for economic purposes, besides the fact that it is adapted to semiarid conditions, the aim of this study was to assess the effects of drought and different doses of organic fertilization supplemented or not with mineral fertilizer in the production, content, yield and chemical composition of essential oil of Lippia gracilis.

\section{Material and methods}

\section{Plant material and cultivation experiment}

The experiment of cultivation of L. gracilis was conducted at Experimental Station of Bebedouro, owned by Embrapa Semi-Arid, located in the city of Petrolina, Pernambuco, Brazil (376 m above sea level; 09 $23^{\prime} 35^{\prime \prime} \mathrm{S}$ and $40^{\circ} 30^{\prime} 27^{\prime \prime} \mathrm{W}$ ) in the period from July to December 2011.
The seedlings were grown from rooting of 144 cuttings of plants collected in a natural population occurring at a Caatinga area next to the institution. Voucher specimen of the species was deposited in the Herbarium of the Semi-Arid Tropic under the record 2774. (Registration Certificate to collect botanical, fungal and microbial materials - Number: 35849-4 / Authorization for activities with scientific purpose - Number: 35800-2).

Seedling planting was carried out in the morning in pre-prepared beds $(1.5 \times 1.0 \mathrm{~m})$, with spacing of $0.5 \mathrm{~m}$ between plants and $1.0 \mathrm{~m}$ between rows. The treatments consisted of different levels of organic fertilizer [tanned sheep/goat manure (1:1): 0, 20, 40 and $60 \mathrm{t} \mathrm{ha}^{-1}$; mineral fertilizer [absence and presence: $0.6 \mathrm{t} \mathrm{ha}^{-1} \mathrm{NPK}$ (159-20)] and drip irrigation (absence and presence: $5.33 \mathrm{~mm} \mathrm{day}^{-1}$ ). The experiment consisted of a full factorial, totaling 16 treatments, being $4 \times 2 \times 2$ (different levels of animal manure $x$ presence and absence of mineral fertilizer $x$ presence and absence of irrigation), which are presented in Table 1.

Soil samples were collected before tillage. The had the following characteristics in soil analysis:

Table 1. Treatments used in the cultivation of Lippia gracillis

\begin{tabular}{|cccc|}
\hline Treatments & $\begin{array}{c}\text { Organic fertilization } \\
\left(\mathbf{t ~ h a}^{-1}\right)\end{array}$ & $\begin{array}{c}\text { Fertilization NPK } \\
(\mathbf{1 5 - 9 - 2 0}) \mathbf{- 0 , 6} \mathbf{t ~ h a}^{\mathbf{- 1}}\end{array}$ & Irrigation \\
\hline & 0 & Yes & Yes \\
1 & 0 & No & Yes \\
2 & 20 & Yes & Yes \\
3 & 20 & No & Yes \\
4 & 40 & Yes & Yes \\
5 & 40 & No & Yes \\
6 & 60 & Yes & Yes \\
7 & 60 & No & Yes \\
8 & 0 & Yes & No \\
9 & 0 & No & No \\
10 & 20 & Yes & No \\
11 & 20 & No & No \\
12 & 40 & Yes & No \\
13 & 40 & No & No \\
14 & 60 & Yes & No \\
15 & 60 & No & No \\
16 & & & \\
\hline
\end{tabular}


$\mathrm{pH}=6.8, \mathrm{P}=8.87 \mathrm{mg} \mathrm{dm}{ }^{-3}, \mathrm{~K}=0.31 \mathrm{cmol}_{\mathrm{c}} \mathrm{dm}^{-3}$, $\mathrm{Ca}=1.9 \mathrm{cmol}_{\mathrm{c}} \mathrm{dm}^{-3}, \mathrm{Mg}=0.5 \mathrm{cmol}_{\mathrm{c}} \mathrm{dm}^{-3}, \mathrm{Na}=$ $0.02 \mathrm{cmol}_{\mathrm{c}} \mathrm{dm}^{-3}, \mathrm{Al}=0.05 \mathrm{cmol}_{\mathrm{c}} \mathrm{dm}^{-3}, \mathrm{H}+\mathrm{Al}=$ $1.48 \mathrm{cmol}_{\mathrm{c}} \mathrm{dm}^{-3}$, sum of bases $(\mathrm{SB})=2.73 \mathrm{cmol}_{\mathrm{c}}$ $\mathrm{dm}^{-3}$, cation exchange capacity $(\mathrm{T})=4.21 \mathrm{cmol}_{\mathrm{c}}$ $\mathrm{dm}^{-3}$, base saturation $(\mathrm{V})=65 \%$, organic matter $(\mathrm{OM})=7.03 \mathrm{~g} \mathrm{~kg}^{-1}$, Saturated Extract $(\mathrm{CE})=0.34$ $\mathrm{dS} \mathrm{m} \mathrm{m}^{-1}$.

The experimental design was conducted in randomized blocks with three replications. Each plot consisted of three plants. Plants were harvested after 120 days of cultivation, in the morning for the extraction of essential oils (EOs). Bordering plants were discarded. The variables analyzed were: total length until the last leaf, fresh weight of aerial parts with stem (FWAP), leaf fresh weight (LFW) and dry weight (LDW), content $(\%)$ and chemical composition of essential oil, and moisture.

EO extraction and GC-MS and GC-FID analysis

L. gracilis leaves were dried at $40 \pm 1^{\circ} \mathrm{C}$ for four days in the oven (Marconi MA 037). The dried leaves were cut into pieces and subjected to hydrodistillation for four hours in a modified Clevenger-type apparatus. The hydrodistillation was repeated three times. For the determination of moisture, 5 grams of raw material emerged in $50 \mathrm{ml}$ of cyclohexane $\left(\mathrm{C}_{6} \mathrm{H}_{12}\right)$ were used separately, placed in a volumetric flask with a capacity of $250 \mathrm{ml}$, coupled with a condenser and a volumetrically graduated collector. Heating was accomplished by heating mantle with temperature controlled at $100 \pm 5^{\circ} \mathrm{C}$. After the distillation process, which occurred within four hours, it was quantified the amount of water present in the raw materials. The moisture was calculated taking into consideration the water content present in 100 grams of sample ${ }^{12,13}$. At the end of the procedure, the EO average yield from three hydrodistillations of L. gracilis was calculated and then, the oil was separated from the aqueous phase and kept in freezer until use.

The analysis of components of essential oils was carried out using GC-MS/GC-FID (GC-2010 Plus; GCMS-QP2010 Ultra, Shimadzu Corporation, Kyoto, Japan) equipped with an autosampler AOC-20i (Shimadzu). The separations were carried out using a fused silica capillary column
Rtx ${ }^{\circledR}-5 \mathrm{MS}$ Restek (polysiloxane $5 \%$-diphenyl $95 \%$-dimethyl) with $30 \mathrm{~m} \times 0.25 \mathrm{~mm}$ of internal diameter (i.d.), film thickness of $0.25 \mathrm{~mm}$, at a constant flow of helium (99.999\%) with a rate of $1.2 \mathrm{ml} \mathrm{min}^{-1}$. It was used an injection volume of $0.5 \mathrm{uL}\left(5 \mathrm{mg} \mathrm{ml}^{-1}\right)$ with a 1:10 split ratio. The oven temperature programming used was from $50^{\circ} \mathrm{C}$ (isothermal for $1.5 \mathrm{~min}$.) with an increase of $4^{\circ} \mathrm{C} / \mathrm{min}$. to $200^{\circ} \mathrm{C}$, then $10^{\circ} \mathrm{C} / \mathrm{min}$. to $250^{\circ} \mathrm{C}$, finishing with an isotherm for $5 \mathrm{~min}$. at $250^{\circ} \mathrm{C}$.

The GC-MS and GC-FID data were acquired simultaneously using a separation detector system; the flow split ratio was 4:1 (MS:FID). A restrictor pipe with $0.62 \times 0.15 \mathrm{~mm}$ i.d. (capillary column) was used to connect the splitter to the MS detector; a restrictor tube with $0.74 \mathrm{~m} \mathrm{x}$ $0.22 \mathrm{~mm}$ i.d. was used to connect the splitter to the FID detector. The injector temperature was $250^{\circ} \mathrm{C}$ and the ion source temperature was $200^{\circ} \mathrm{C}$. The ions were generated at $70 \mathrm{eV}$; at a 0.3 fragments scan rate (scans) $\mathrm{s}^{-1}$ detected in the range of 40-350 Da. FID temperature was adjusted to $250^{\circ} \mathrm{C}$, and gas supplies to the FID were synthetic air, hydrogen, helium at flow rates of 30, 300 and $30 \mathrm{ml} \mathrm{min}{ }^{-1}$, respectively. The quantification of each constituent was realized standard method. Estimated by normalizing the peak area generated at FID-(\%). The concentrations of the compounds were calculated from the GC peak areas and were disposed by GC elution order.

The identification of the components was performed based on comparison of retention indices in literature. For the retention index, the equation of Van den Dool and Kratz ${ }^{14}$ was used relative to a homologous series of $n$-alkanes $\left(\mathrm{nC}_{9}\right.$ $\mathrm{nC}_{18}$ ). Three libraries of the equipment WILEY8, NIST107 and NIST21 were used, which allows data comparison of the spectra with those contained in the libraries using an $80 \%$ similarity index.

The obtained data were preliminarily analyzed in order to meet the basic hypotheses of ANOVA: additivity, independence, homoscedasticity and normality. The general model adopted for the test was:

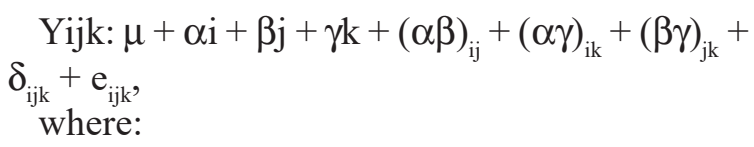
$\mu$ : constant inherent in all installments, 
$\alpha \mathrm{i}$ : effect of organic fertilizer,

$\beta \mathrm{j}$ : effect of mineral fertilizer,

$\gamma \mathrm{k}$ : effect of irrigation,

$\alpha \beta_{\mathrm{ij}}$ interaction effect of organic fertilizer and mineral fertilizer,

$\beta \gamma_{\mathrm{jk}}$ : interaction effect of mineral fertilizer and irrigation,

$\alpha \gamma_{\mathrm{ik}}$ : interaction effect of organic fertilizer and irrigation,

$\delta_{i \mathrm{ji}}:$ interaction effect of organic fertilizer, mineral fertilizer and irrigation,

$\mathrm{e}_{\mathrm{ij}}$ : experimental error associated to each installment.

Data were subjected to analysis of variance (5 $\%$ significance) and polynomial regression using Sisvar software ${ }^{15}$.

\section{Results and discussion}

Biomass, essential oil concentration and yield

The height of the last leaf was influenced by the significant interaction irrigation $\mathrm{x}$ organic fertilizer $\mathrm{x}$ mineral fertilizer $(\mathrm{p}<0.05)$. There was quadratic effect for all combinations of irrigation and mineral fertilization depending on the organic fertilizer levels. The greatest height of the last leaf $(1.16 \mathrm{~m})$ was obtained on the combination no irrigation $\mathrm{x}$ mineral fertilizer at a dosage of 49 $\mathrm{t} / \mathrm{ha}$ of organic fertilizer. The lower performance of this variable $(0.75 \mathrm{~m})$ was observed on combination irrigation $\mathrm{x}$ no mineral fertilizer when applied $7.5 \mathrm{t} / \mathrm{ha}$ of organic fertilizer (Fig. 1A).

Regarding the PWAP, it was observed that there was a significant quadratic effect of the interac- tion irrigation $\mathrm{x}$ organic fertilizer and also of mineral fertilizer. Different dosages of organic fertilization with irrigation performed better regarding the absence of irrigation. With irrigation, larger FWAP (430.72 g) was obtained at a dose of $37.17 \mathrm{t} / \mathrm{ha}$. The effect of mineral fertilization on this variable was positive, where FWAP obtained an average of $347.05 \mathrm{~g}$ with fertilization versus $229.75 \mathrm{~g}$ without fertilization, showing a difference of $51.06 \%$.

The FWAP was significantly influenced by the levels of organic fertilization and the interaction irrigation and mineral fertilization $(\mathrm{p}<0.05)$ (Fig. 1B). From the regression curve adjustment it was observed that as there was an increase with organic fertilization, an increase of FWAP was noted until the dosage of $35.32 \mathrm{t} / \mathrm{ha}$. From this level began the decline of the values obtained for this variable.

The leaf fresh weight (LFW), dry weight (LDW) and humidity, varied only according to the doses of organic fertilization (Figure 1C, 1D and $1 \mathrm{E}$ ).

Santos ${ }^{16}$ observed no significant differences between treatments of organic fertilization on the content of leaf dry matter and essential oil of Lippia alba. In studies with Lippia sidoides ${ }^{17}$ concluded that the increased production of dry biomass of this species was obtained at the highest dose $\left(6.0 \mathrm{~kg} / \mathrm{m}^{2}\right)$ of poultry manure.

In studies of organic fertilizer in Lippia citriodora ${ }^{18}$ observed that the production of fresh and dry biomass was higher with the application

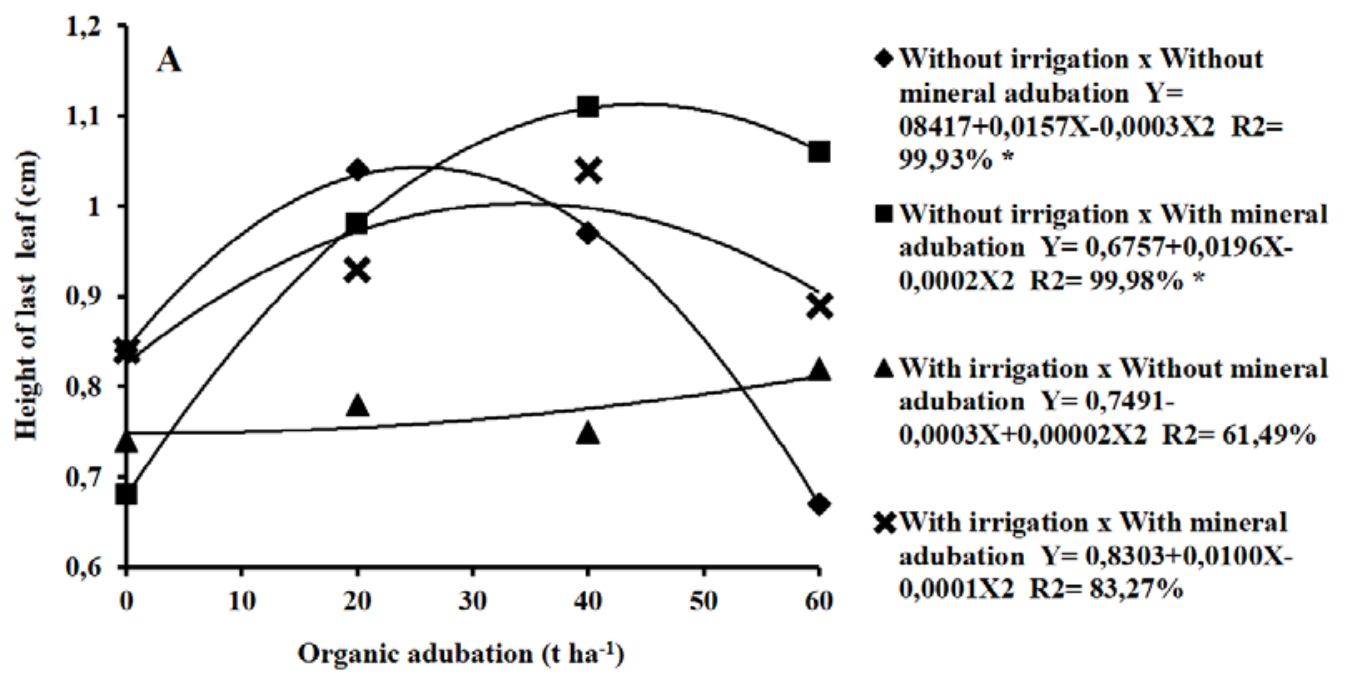



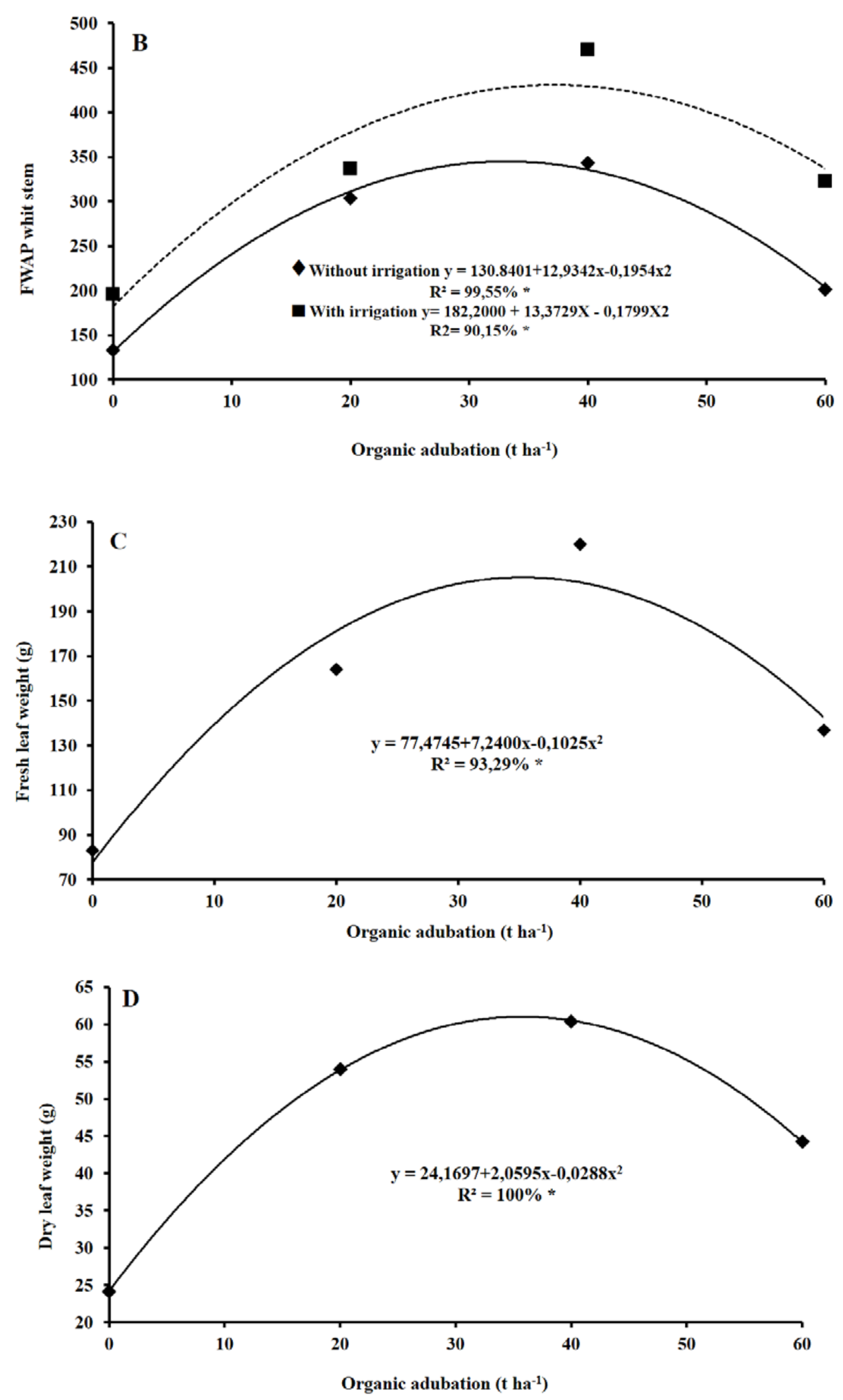

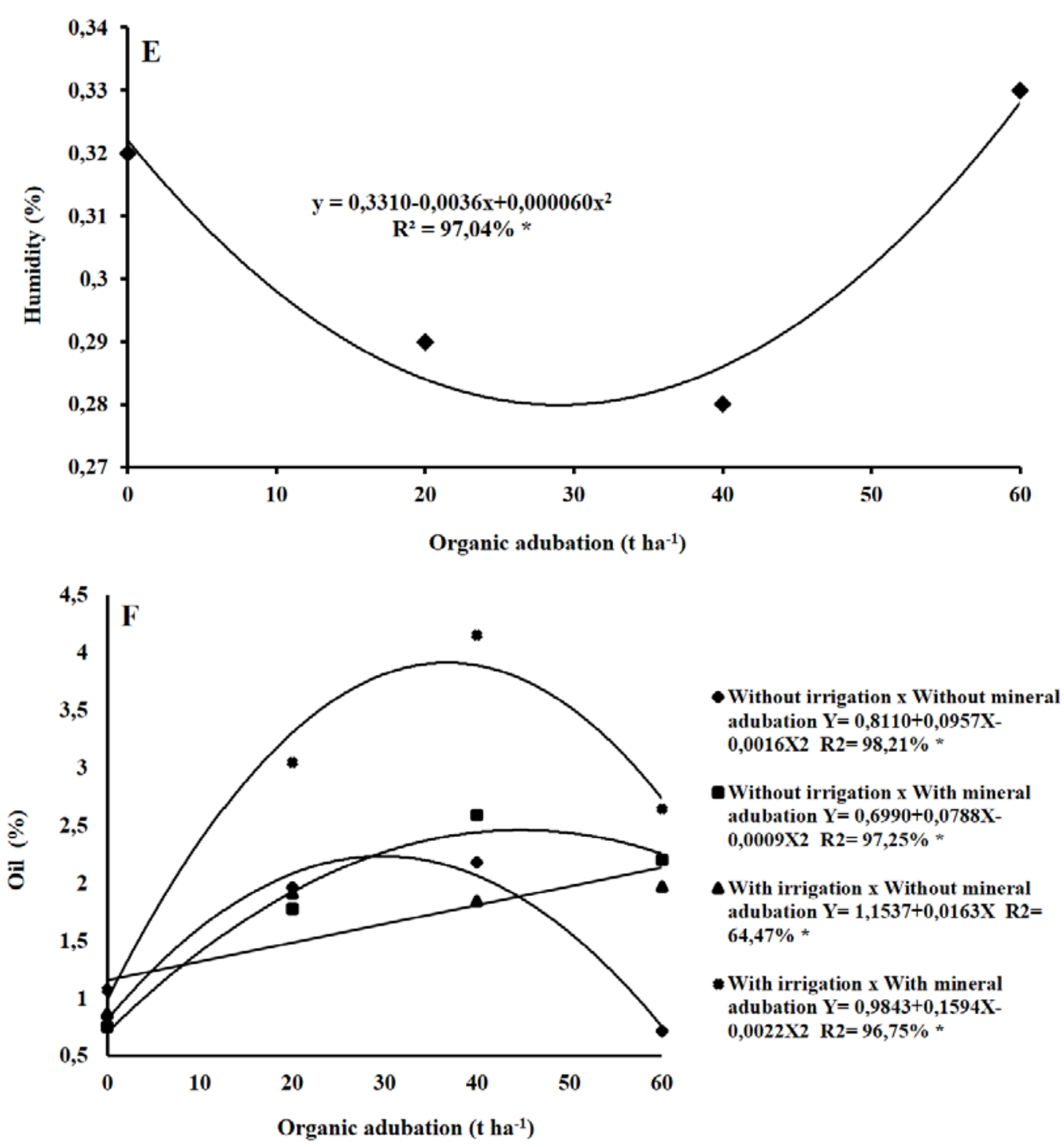

Figure 1. Last leaf height of Lippia gracilis with organic adubation, in the presence and absence of mineral adubation, with and without irrigation (A), fresh weight of aerial parts with stem of Lippia gracilis with organic adubation with and without irrigation (B), fresh leaf weight of Lippia gracilis with organic adubation (C), dry weight of leaves of Lippia gracilis with organic adubation (D), humidity leaf of Lippia gracilis with organic adubation (E) and oil content of Lippia gracilis with organic adubation, in the presence and absence of mineral adubation, with and without irrigation $(\mathrm{F})$.

of cattle manure.

It was observed that when fertilizing the soil with mineral fertilizer, irrigation did not influence the fresh leaf biomass for the species under study. However, if there is no mineral fertilization, the presence of water can induce higher plant growth and hence higher production of fresh biomass (Table 2 and 3 ).

When Dhru ${ }^{19}$ studied the effect of water stress on biomass production of medicinal species Nerium oleander and Urginea indica, it was noted that the drought reduced biomass production in both. In contrast ${ }^{20}$ observed an increase in the yield of two cultivars of parsley (Petroselinum crispum) when subjected to water stress.

Water is an essential factor to life and metabolism of plants, assuming that in more humid environments the production of secondary metabo- 
Table 2. Interaction effect of irrigation and mineral fertilization on the weight of fresh biomass of Lippia gracilis leaves

\begin{tabular}{|c|c|c|}
\hline \multirow[t]{2}{*}{ Irrigation } & \multicolumn{2}{|c|}{ Mineral fertilization* } \\
\hline & Yes & No \\
\hline Yes & $232.22 \mathrm{aA}$ & $131.18 \mathrm{aB}$ \\
\hline No & $131.87 \mathrm{aA}$ & $109.10 \mathrm{bA}$ \\
\hline
\end{tabular}

* Means followed by the same lower case letter in the column and capital on the line do not differ by Scott and Knott test at $5 \%$ probability

Table 3. Effect of mineral fertilization and irrigation on leaf dry weight (LDW) of Lippia gracilis

\begin{tabular}{|lc|}
\hline Mineral fertilization & LDW (g)* \\
\hline Yes & $53.51 \mathrm{a}$ \\
No & $37.88 \mathrm{~b}$ \\
& \\
Irrigation & \\
Yes & $51.18 \mathrm{a}$ \\
No & $4.022 \mathrm{~b}$ \\
\hline
\end{tabular}

* Means followed by the same lower case letter in the column and capital on the line do not differ by Scott and Knott test at $5 \%$ probability

lites is greater. However, this does not always occur, and the results are variable among species. The water factor significantly influences the growth and development of the plant as a whole as well as the concentration of secondary metabolites. In this case, one must consider the degree of stress and the occurrence period. According ${ }^{21}$ the short term effects may result in increase of this concentration, while in the long run an opposite effect can be observed.

The EO content was influenced by the interaction of three factors studied: organic fertilization, mineral fertilization and irrigation $(\mathrm{p}<0.05)$. The higher EO content $(3.87 \%)$ of L. gracilis was obtained from the combination of the presence of mineral fertilization and irrigation when the soil was fertilized with $36.23 \mathrm{t} / \mathrm{ha}$ of organic fertilizer (Fig. 1F). In other combinations, it was obtained a maximum yield of $2.42 \%$ of oil (no irrigation, but with mineral fertilization when the soil was fertilized with $43.77 \mathrm{t} /$ ha of manure) followed by $2.24 \%$ of oil (no irrigation and no min- eral fertilization, when the soil was fertilized with $29.90 \mathrm{t} / \mathrm{ha}$ of organic fertilizer. In the combination of irrigation with no mineral fertilization, there was linear effect of organic fertilizer levels on oil content, however, less expressive than the other combinations.

To assess the biomass and essential oil yields in Justicia pectoralis var. stenophylla, ${ }^{22}$ used different doses of organic and mineral fertilizer and as a result found that these fertilizers did not influence plant growth. The EO yield showed a decreasing trend with the increase in levels of bovine manure in each of the formulations of mineral fertilizer. These results contrast with the results obtained for Lippia gracilis, since the handling conditions positively influenced in biomass and EO yield.

Silva ${ }^{23}$ observed that the severe drought for the species Melaleuca alternifolia Cheel, resulted in a decrease in the growth, production of fresh and dry biomass of plants and EO content when compared to the treatment which received daily 
irrigation of a liter of water. These results are similar to those for the species L. gracilis, where there was a higher yield of EO when the plant was subjected to organic fertilization, mineral fertilization and in the presence of irrigation. This probably occurs because this treatment has micro and macro nutrients present in the mineral and organic fertilizers, and the presence of water to facilitate the absorption of these nutrients by plants. However, it is important to consider the chemical composition of the EO, once the content of certain compounds of interest for chemical and pharmaceutical industries, can be increased by water stress conditions.

According ${ }^{24}$ technical factors also should be highlighted, such as the way of planting and plant health aspects that determine the overall state of development of plants and hence their greater or lesser productivity. The phytotechnical resources used during the process of production of medicinal plants can be characterized as a source of stimulation for the production of active principles of interest.
Thus, once the plant has genetic information to produce active principles, the yield can be altered by biotic and abiotic factors of the environment where they are. The systematic study of all relevant steps for growing of plants producing bioactive substances is important, since one or more factors may determine the final quality of the product whether it is a medicine or products with biopesticide activity for use in agriculture. Moisture was influenced only by the levels of organic fertilization. There was quadratic effect because as the level of organic fertilizer rises there is a moisture decrease until the dosage of $30 \mathrm{t} / \mathrm{ha}$. From this level on, moisture content of leaves of L. gracilis rises again.

\section{Constituents of Essential Oils of Lippia gra-} cilis

In Table 4 the composition of the EOs of $L$. gracilis grown on different management systems can be observed. On average, $97 \%$ of the constituents of EOs were identified, the majority ( 87 $\%$ ) represented by monoterpenes. The carvacrol

Table 4. Chemical composition characterized by GC-MS and GC-FID essential oils of Lippia gracilis plants cultived whithout irrigation and different agricultural practices

\begin{tabular}{|c|c|c|c|c|c|c|c|c|c|}
\hline \multirow{4}{*}{ Substance } & \multirow{4}{*}{$\mathbf{I R}^{a}$} & \multicolumn{8}{|c|}{ Absence irrigation $^{b}$} \\
\hline & & \multirow{2}{*}{\multicolumn{8}{|c|}{$\begin{array}{cc}\text { Without NPK } & 0.6 \mathrm{t} \mathrm{ha}^{-1} \text { NPK }(15-9-20) \\
\text { Organic fertilizer [tanned sheep/goat manure }(1: 1)\left(\mathrm{t} \mathrm{ha}^{-1}\right)\end{array}$}} \\
\hline & & & & & & & & & \\
\hline & & $\mathbf{0}$ & 20 & 40 & 60 & $\mathbf{0}$ & 20 & 40 & 60 \\
\hline$\alpha$-Thujene & 945 & 0.03 & - & 0.04 & - & - & 0.05 & 0.19 & 0.03 \\
\hline$\alpha$-Pinene & 951 & 0.02 & - & - & - & - & - & 0.15 & - \\
\hline 1-Octen-3-ol & 984 & 0.16 & 0.09 & 0.13 & 0.08 & - & 0.09 & - & 0.04 \\
\hline Myrcene & 994 & 0.34 & 0.37 & 0.40 & 0.31 & 0.35 & 0.49 & 0.64 & 0.46 \\
\hline$\alpha$-Terpinene & 1020 & 0.17 & 0.26 & 0.23 & 0.06 & 0.18 & 0.25 & 0.39 & 0.25 \\
\hline$\rho$-Cymene & 1027 & 2.51 & 2.65 & 2.39 & 2.68 & 2.40 & 3.16 & 3.67 & 3.19 \\
\hline 1.8-Cineol & 1034 & 0.38 & 0.99 & - & 0.64 & - & 0.24 & 1.03 & 0.16 \\
\hline E- $\beta$-Ocimene & 1048 & 0.02 & - & - & - & - & - & 0.09 & - \\
\hline$\gamma$-Terpinene & 1061 & 1.00 & 1.49 & 1.39 & 0.35 & 1.01 & 1.35 & 2.14 & 1.44 \\
\hline cis-Sabinene hydrate & 1069 & 0.42 & 0.27 & 0.40 & 0.38 & 0.25 & 0.40 & 0.40 & 0.25 \\
\hline Linalool & 1102 & 0.48 & 0.42 & 0.35 & 0.45 & 0.38 & 0.53 & 0.59 & 0.38 \\
\hline Ipsdienol & 1148 & 0.53 & 0.53 & 0.45 & 0.63 & 0.45 & 0.61 & 0.59 & 0.63 \\
\hline Terpinen-4-ol & 1181 & 0.64 & 0.77 & 0.64 & 0.56 & 0.71 & 0.68 & 0.75 & 0.71 \\
\hline Thymol methyl ether & 1238 & 2.31 & 2.58 & 1.65 & 1.36 & & 1.39 & 2.35 & 2.05 \\
\hline Carvacrol methyl ether & 1247 & 0.33 & 0.27 & 0.30 & 0.32 & 0.23 & 0.25 & 0.28 & 0.30 \\
\hline Thymol & 1297 & 6.3 & 5.1 & 9.5 & 7.0 & 14.3 & 7.1 & 5.6 & 5.4 \\
\hline
\end{tabular}


table 4. (continued).

\begin{tabular}{|c|c|c|c|c|c|c|c|c|c|}
\hline \multirow{4}{*}{ Substance } & \multirow{4}{*}{$\mathbf{I R}^{a}$} & \multicolumn{8}{|c|}{ Absence irrigation $^{b}$} \\
\hline & & \multirow{2}{*}{\multicolumn{8}{|c|}{$\begin{array}{cc}\text { Without NPK } & 0.6 \mathrm{t} \mathrm{ha}^{-1} \text { NPK }(15-9-20) \\
\text { Organic fertilizer [tanned sheep/goat manure }(1: 1)\left(\mathrm{t} \mathrm{ha}^{-1}\right)\end{array}$}} \\
\hline & & & & & & & & & \\
\hline & & $\mathbf{0}$ & 20 & 40 & 60 & $\mathbf{0}$ & 20 & 40 & 60 \\
\hline Carvacrol & 1311 & 78.6 & 76.5 & 75.6 & 77.0 & 71.5 & 78.0 & 76.8 & 74.9 \\
\hline Thymol acetate & 1358 & - & 0.15 & & & 0.10 & - & - & 0.21 \\
\hline Carvacrol acetate & 1375 & & 0.97 & 0.14 & 0.12 & 0.26 & 0.29 & 0.25 & 1.70 \\
\hline E-Caryophyllene & 1425 & 1.24 & 3.01 & 1.77 & 1.28 & 2.32 & 1.56 & 1.25 & 2.85 \\
\hline Aromadendrene & 1443 & 0.03 & - & - & 0.24 & - & - & 0.06 & 0.06 \\
\hline$\alpha$-Humulene & 1458 & 0.26 & 0.06 & 0.48 & 0.04 & 0.66 & 0.26 & & 0.20 \\
\hline ar-Curcumene & 1484 & - & - & - & - & & - & - & - \\
\hline$\alpha$-Zingiberene & 1496 & - & - & - & - & - & - & - & - \\
\hline$\beta$-Bisabolene & 1509 & 0.17 & 0.23 & 0.34 & 0.32 & 0.48 & 0.16 & 0.03 & 0.14 \\
\hline$\delta$-Cadinene & 1526 & - & - & 0.21 & - & 0.32 & & 0.04 & 0.46 \\
\hline Spathulenol & 1584 & 0.26 & 0.27 & 0.19 & 0.68 & 0.24 & 0.30 & 0.27 & 0.32 \\
\hline Caryophyllene oxide & 1591 & 0.85 & 1.00 & 0.76 & 1.98 & 1.56 & 0.76 & 0.58 & 1.05 \\
\hline Humulene epoxide & 1616 & 0.03 & - & 0.04 & - & 0.22 & - & - & - \\
\hline Total detected (\%) & 97.1 & 98.0 & 97.4 & 96.5 & & 97.9 & 97.9 & 98.2 & 97.2 \\
\hline Content $\%(\mathrm{v} / \mathrm{m})^{c}$ & $0.85 b$ & $5.9 \mathrm{a}$ & $4.7 \mathrm{a}$ & $2.1 \mathrm{~b}$ & & $1.8 \mathrm{~b}$ & $5.5 \mathrm{a}$ & $6.5 \mathrm{a}$ & $2.9 b$ \\
\hline
\end{tabular}

${ }^{a}$ Retention Index calculated using the equation de Van den Dool e Kratz 1963 relative to a homologous series

${ }^{\mathrm{b}}$ Content values of the compounds obtained by averaging three different determinations obtained by GC / MS and GC / FID

Dashes indicate that the compound was not found

${ }^{\mathrm{c}}$ Means followed by the same letter do not differ by the Scott-Knott $\mathrm{p}<0.05$ test

$(76.8 \pm 0.32 \%)$ was the major component of the EOs, followed by thymol $(6.98 \pm 0.36 \%)$ and $\rho$ cymene $(2.55 \pm 0.10 \%)$. The variation in carvacrol content in oils of plants that have been subjected to different handling conditions was low. However, thymol content was higher in plants fertilized with NPK, without organic fertilization and which were not irrigated. Other essays with L. gracilis presented the same major compounds at concentrations similar to those found in this study ${ }^{11}$ (Table 4 and 5).

Some studies have shown that the availability of water and nutrients influences on the composition of EOs in plants. The concentration of carvacrol in EO of Satureja hortensis L. increased with the intensification of drought ${ }^{25}$ and irrigation and organic fertilization increased the concentration of cuminic aldehyde and $\rho$-cymene and reduced $\beta$-pinene, $\gamma$-terpinene and $\alpha$-pinene in the
EO of Cuminum cyminum L. ${ }^{26}$.

When the plants were not irrigated and were fertilized with NPK, a negative correlation between the amount of organic fertilizer and thymol content $(r=-0.86)$ and carvacrol $(r=-0.80)$ was found, that is, the greater the amount of this fertilizer the lower the content of these substances. The opposite occurred for thymol when plants were irrigated $(r=0.80)$. Therefore, it is concluded that if the plants are irrigated, the NPK or organic fertilization provides increased thymol content. When the objective is to obtain an oil rich in carvacrol, the best growing condition is achieved with no irrigation and no mineral or organic fertilization.

In studies on the effects of fertilization with bovine manure ${ }^{27}$ analyzed the doses of $0,5,10,20$ and $30 \%$ of bovine manure on the content and chemical composition of the essential oil of 
Table 5. Chemical composition characterized by GC-MS and

GC-FID essential oils of Lippia gracilis plants irrigated and cultived with different agricultural practices

\begin{tabular}{|c|c|c|c|c|c|c|c|c|c|}
\hline \multirow{4}{*}{ Substance } & \multirow{4}{*}{$\mathbf{I R}^{a}$} & \multicolumn{8}{|c|}{ Absence irrigation $^{b}$} \\
\hline & & \multirow{2}{*}{\multicolumn{8}{|c|}{$\begin{array}{cc}\text { Without NPK } & 0.6 \mathrm{t} \mathrm{ha}^{-1} \text { NPK }(15-9-20) \\
\text { Organic fertilizer [tanned sheep/goat manure }(1: 1)\left(\mathrm{t} \mathrm{ha}^{-1}\right)\end{array}$}} \\
\hline & & & & & & & & & \\
\hline & & $\mathbf{0}$ & 20 & 40 & 60 & $\mathbf{0}$ & 20 & 40 & 60 \\
\hline$\alpha$-Thujene & 945 & 0.07 & 0.06 & 0.02 & 0.09 & & - & - & 0.07 \\
\hline$\alpha$-Pinene & 951 & 0.07 & - & 0.02 & 0.03 & & - & - & - \\
\hline 1-Octen-3-ol & 984 & - & 0.05 & 0.09 & 0.02 & & - & 0.07 & 0.06 \\
\hline Myrcene & 994 & 0.32 & 0.37 & 0.28 & 0.43 & & 0.31 & 0.33 & 0.36 \\
\hline$\alpha$-Terpinene & 1020 & 0.26 & 0.20 & 0.12 & 0.26 & & 0.15 & 0.16 & 0.24 \\
\hline$\rho$-Cymene & 1027 & 2.32 & 2.63 & 1.68 & 2.59 & & 2.22 & 2.35 & 2.37 \\
\hline 1.8-Cineol & 1034 & 0.85 & - & - & 0.69 & & 0.56 & 0.19 & 1.66 \\
\hline E- $\beta$-Ocimene & 1048 & - & 0.07 & - & - & & 0.03 & 0.08 & - \\
\hline$\gamma$-Terpinene & 1061 & 1.89 & 1.28 & 0.68 & 1.37 & & 0.84 & 0.79 & 1.76 \\
\hline cis-Sabinene hydrate & 1069 & 0.38 & 0.29 & 0.21 & 0.38 & & 0.29 & 0.27 & 0.42 \\
\hline Linalool & 1102 & 0.89 & 0.60 & 1.06 & 0.39 & & 0.58 & 0.45 & 0.63 \\
\hline Ipsdienol & 1148 & 0.42 & 0.65 & 0.76 & 0.61 & & 0.68 & 0.82 & 0.51 \\
\hline Terpinen-4-ol & 1181 & 0.82 & 0.66 & 0.70 & 0.63 & & 0.64 & 0.74 & 0.68 \\
\hline Thymol methyl ether & 1238 & 2.36 & 2.30 & 0.46 & 2.38 & & 1.82 & 1.88 & 1.35 \\
\hline Carvacrol methyl ether & 1247 & 0.23 & 0.35 & 0.26 & 0.23 & & 0.20 & 0.19 & 0.25 \\
\hline Thymol & 1297 & 4.9 & 4.9 & 8.0 & 5.2 & & 5.7 & 6.2 & 6.0 \\
\hline Carvacrol & 1311 & 76.2 & 77.3 & 74.8 & 78.3 & & 74.9 & 79.0 & 73.9 \\
\hline Thymol acetate & 1358 & - & 0.13 & - & - & & 0.16 & - & 0.39 \\
\hline Carvacrol acetate & 1375 & 0.38 & 0.65 & 0.45 & 0.11 & & 1.03 & 0.37 & 1.78 \\
\hline E-Caryophyllene & 1425 & 2.55 & 1.56 & 4.53 & 1.50 & & 3.85 & 1.54 & 2.65 \\
\hline Aromadendrene & 1443 & 0.41 & 0.25 & 0.33 & 0.32 & & 0.07 & - & - \\
\hline$\alpha$-Humulene & 1458 & - & - & 0.30 & - & & 0.27 & - & - \\
\hline ar-Curcumene & 1484 & - & - & 0.20 & - & & - & - & - \\
\hline$\alpha$-Zingiberene & 1496 & - & - & 0.67 & - & & - & - & - \\
\hline$\beta$-Bisabolene & 1509 & 0.23 & 0.37 & 0.52 & 0.17 & & 0.51 & & 0.28 \\
\hline$\delta$-Cadinene & 1526 & 0.26 & - & 0.31 & - & & - & - & - \\
\hline Spathulenol & 1584 & 0.61 & 0.33 & 0.22 & 0.29 & & 0.20 & 0.22 & 0.35 \\
\hline Caryophyllene oxide & 1591 & 1.20 & 1.28 & 1.11 & 0.70 & & 1.41 & 0.92 & 1.29 \\
\hline Humulene epoxide & 1616 & - & - & - & - & & - & - & - \\
\hline Total detected (\%) & 97.7 & 96.3 & 97.8 & 96.7 & & 96.4 & 96.6 & 97.0 & 97.4 \\
\hline Content $\%(\mathrm{v} / \mathrm{m})^{c}$ & $2.60 \mathrm{~b}$ & $5.7 \mathrm{a}$ & $4.6 \mathrm{a}$ & $5.1 \mathrm{a}$ & & $3.2 b$ & $6.8 \mathrm{a}$ & $9.0 \mathrm{a}$ & $7.3 \mathrm{a}$ \\
\hline
\end{tabular}

${ }^{a}$ Retention Index calculated using the equation de Van den Dool e Kratz 1963 relative to a homologous series

${ }^{\mathrm{b}}$ Content values of the compounds obtained by averaging three different determinations obtained by GC/ MS and GC / FID

Dashes indicate that the compound was not found

${ }^{\mathrm{c}}$ Means followed by the same letter do not differ by the Scott-Knott $\mathrm{p}<0.05$ test 
Baccharis trimera, and as a result found that there was no effect of the absence and presence of fertilization for carquejol and carquejila acetate.

The deficit of phosphorus in the soil reduces the concentration of coumarins in Chamba (Justicia pectoralis var. stenophylla) having as most detrimental effect, the decrease in phytomass production, with a consequent reduction in the overall production of the active principle ${ }^{22}$.

\section{Conclusion}

The conditions in which this study was con- ducted allowed to conclude that organic fertilization, mineral fertilization and irrigation positively influence the production of biomass and essential oil content of Lippia gracilis. However, the cultivation practices did not significantly affect the composition of the EOs in this species, which shows its rusticity to changes in availability of water and nutrients. This indicates that cultivation of $L$. gracilis may be performed by small and medium farmers with little investment, focusing on qualitative and quantitative homogeneity of the constituents of industrial interest.

\section{References}

1. Pascual, M.E., Slowing, K., Carretero, E., Sanchez Mata, D. and Villar, A. (2001). Review - Lippia: traditional uses, chemistry and pharmacology: a review. Journal of Ethnopharmacology. 76: 201-214.

2. Albuquerque, U.P., Medeiros, P.M., Almeida, A.L.S., Monteiro, J.M., Neto, E.M.F.L., Melo, J.G. and Santos, J.P. (2007). Medicinal plants of the caatinga (semi-arid) vegetation of NE Brazil: A quantitative approach. Journal of Ethnopharmacology. 114: 325-354.

3. Mendes, S.S., Bomfim, R.R., Jesus, H.C.R., Alves, P.B., Blank, A.F., Estevam, C.S., Antonio, A.R. and Thomazzi, S.M. (2010). Evaluation of the analgesic and anti-inflammatory effects of the essential oil of Lippia gracilis leaves. Journal of Ethnopharmacology. 129: 391-397.

4. Albuquerque, C.C., Camara, T.R., Mariano, R.L.R., Willadino, L., Marce Júnior, C. and Ulisses, C. (2006). Antimicrobial action of the essential oil of Lippia gracilis Schauer. Brazilian Archives of Biology and Technology: an International Journal. 49(4): 527-535.

5. Neves, L.A., Oliveira, J.C.S., Camara, C.A.G. and Schwartz, M.O.E. (2008). Chemical Composition of the Leaf Oils of Lippia gracilis Schauer from two localities of Pernambuco. The Journal of Essential Oil Research. 20(2): 157-160.

6. Dantas, L.I.S., Rocha, F.A.G., Medeiros, F.G.M. and Santos, J.A.B. Antibacterial activity of essential oil of Lippia gracilis Schauer on pathogens of importance in the food industry. Holos. 5: 114.

7. Santos, M.R.A., Innecco, R. (2004). Organic fertilization and cutting height of Lippia Alba. Brazilian Horticulture. 22(2): 182-185.

8. Santos, M.R, Fernandes, C.F., Innecco, R. (2006). Effect of organic fertilization on the production of biomass and essential oil of Lippia alba. Bulletin of Research and Development. Embrapa, n.32, 10p.

9. Assis B.F.S., Martins E. R. and Souza M. F. (2009). Production of phytomass and essential oil of Alecrim-pimenta (Lippia sidoides Cham.) with organic fertilizer. Brazilian Journal of Agroecology. 4(2): 16-20.

10. Oliveira, A.C.L., Arrigoni-Blank, M.F., Blank, A.F. and Bianchini, F.G. (2011). Production of seedlings of two genotypes of rosemary (Lippia gracilis) as a function of mineral fertilizer, limestone, substrates and containers. Brazilian Journal of Medicinal Plants 13: 35-42.

11. Cruz, E.M.O, Pinto, J.A.O., Fontes, S.S., Arrigoni-Blank, M.F., Bacci, L., Jesus, H.C.R., Santos, D.A., Alves, P.B. and Blank, A.F. (2014). Water Deficit and Seasonality Study on Essential Oil Constituents of Lippia gracilis Schauer Germplasm. The Scientific World Journal. $9 \mathrm{p}$.

12. Aocs Official Method Da2b-42. (1994). Official Methods and Recommended Practices of the 
American Oil Chemists Society. American Oil Chemists Society, Champaign, IL, USA.

13. Pimentel, F.A., Cardoso, M.G., Salgado, A.P.P., Aguiar, P.M., Morais, A.R. and Nelson, D.L. (2006). A convenient method for determination of moisture in aromatic plants. Química Nova. 29: 373-375.

14. Van Den Dool, H. and Kratz, P.D.J.A. (1963). Generalization of the retention index system including linear temperature programmed gas-liquid partition chromatography. Journal of Chromatography A. 11: 463-471.

15. Ferreira, D.F. (2011). Sisvar: a computer statistical analysis system. Science and Agrotecnology. 35: 1039-1042.

16. Santos, R.I. (2004). Basic metabolism and origin of Secondary Metabolites. In: Simões, C.M.O., Schenkel, E.P., Gosmann, G., Mello, J.C.P., Mentz, L.A., Petrovick, P.R. (org.) Pharmacognosy: The Plant to Medicine. 5. ed. UFSC. 1102.

17. Chaves, F.C.M., Facanali, R., Antunes, J.A., Ming, L.C., Marques, M.O.M. and Meireles, M.A.M. (2002). Assessment of biomass, essential oil yield and thymol content in Alecrim-pimenta (Lippia sidoides Cham.) depending on organic fertilization. Brazilian Horticulture. 20(2) Supplement.

18. Souza, M.F., Souza Junior, I.T., Gomes, P.A., Fernandes, L.A., Martins, E. R. Costa, C.A. and Sampaio, R.A. (2010). Liming and organic fertilization in the production of biomass and essential oil in Lippia citriodora Kunth. Brasilian Journal of Medicinal Plants. 12: 401-405.

19. Dhru, P., Gupta, S.K. and Pal, D. (1991). Effect of moisture, temperature and radiation stress on therapeutic yield and biomass production in Nerium oleander and Urginea indica. Advances in Plant Sciences. 4(1): 54-60.

20. Petropoulos, S.A., Daferera, D., Polissiou, M.G. and Passam, H.C. (2008). The effect of water deficit stress on the growth, yield and composition of essential oils of parsley. Scientia Horticulturae. 115: 393-397.

21. Gobbo-Neto, L. and Lopes, N.P. (2007). Medicinal plants: influencing factors in the content of secondary metabolites. New Chemical. 30(2): 374-381.

22. Bezerra, A.M.E., Nascimento Junior, F.T., Leal F. R. and Carneiro, J.G.M.R. (2006). Assessment of biomass yield and essential oil, phosphorus and potassium contents of Chambá (Justicia pectoralis) in response to organic and mineral fertilization. Agronomic Science Magazine. 3: $124-129$.

23. Silva, R.S., Demuner, A.J., Barbosa, L.C.A., Casali, V.W.D., Nascimento, E.A. and Pinheiro, A.L. (2002). Effect of water stress on growth characteristics and essential oil production of Melaleuca alternifolia Cheel. Acta Scientiarum. 24(5): 1363-1368.

24. Corrêa Júnior, C., Cortez, D.A.G., Ming, L.C. and Soares, W. (2006). Fáfia - Brazilian ginseng: agronomic and phytochemicals aspects. Clichetec Ltda: p. 22.

25. Baher, Z.F., Mirza, M., Ghorbanli, M. and Rezaii, M.B. (2002). The influence of water stress on plant height, herbal and essential oil yield and composition in Satureja hortensis L. Flavour and Fragrance. 17: 275-277.

26. Ahmadian, A., Tavassoli, A. and Amiri, E. (2011). The interaction effect of water stress and manure on yield components, essential oil and chemical compositions of cumin (Cuminum cyminum). African Journal of Agricultural Research. 6: 2309-2315.

27. Silva, F.G., Pinto, J.E.B.P., Sales, J.F., Mol, D.J.S. and Divino, S.P. (2006). Influence of manure and fertilizer on Baccharis trimera (Less.) DC. growth and essential oil yield. Herbs, Spices \& Medicinal Plants. 12(1/2): 24-30. 